\title{
FORENSIC ACCOUNTING: A WAY TO FIGHT, DETER AND DETECT FRAUD
}

\author{
Jonika Lamba, Dr. Esha Jain (Ph.D.) \\ The NorthCap University, Gurugram, India
}

\begin{abstract}
Forensic Accounting is one of the emerging fields for accountancy professionals. Forensic Accounting is the function of bookkeeping, auditing and analytical expertise to combat the financial and white-collar crimes. The scope of forensic accounting has expanded due to cases of corporate scams and financial frauds. Forensic Accounting is the dynamic and strategic tool which helps in combating the corruption, financial crimes and frauds through the application of forensic auditing techniques. There is a huge demand for forensic auditors in the field of insurance, banks, police armed forces and government departments. This paper shows the application of information technology and cyber forensics to curb the malfunctioning done by corporate. In this paper role of the forensic auditor has been explained and the various techniques employed by forensic auditors have also been discussed. The latest cases in the field of forensic accounting have also been included in this paper. Forensic auditors can help the economy to grow and protect the interest of various stakeholders.
\end{abstract}

Key words: $\quad$ Accounting, auditors, crimes, forensic, frauds.

\section{Introduction}

Forensic accounting is the emerging accounting field due to increased financial and professional violations. Forensic accounting is the incorporation of bookkeeping, examining, and insightful aptitudes. The term fraud has been defined differently under various laws such as the Indian Contract Act, 1872, Companies Act 2013, Indian Penal Code 1860, Criminal Procedure Code, 1973. In short, fraud is the covering of any reality or maltreatment of the position with the intent to deceive and gain undue advantage over the other party. The numbers of fraudulent activities have been accelerating all over the world such as scams of Satyam, Enron, and WorldCom, etc. Forensic Accounting is the dynamic and strategic tool which helps in combating the corruption, financial crimes, and frauds through the application of forensic auditing techniques such as trend analysis, ratio analysis, CAATs ( Computer Assisted Auditing Techniques), Generalized Audit Software, Data Mining Techniques, Forensic analysis of material and electronic evidence. The aim of forensic accounting is to identify the culprit behind the fraud and restore the downgraded public confidence in corporate functioning. In India, frauds have been rising at a fast pace due to a lack of proper monitoring and control systems. Companies have to comply with the laws and regulations so that they are less prone to penalties and legal actions and it will help them to emerge as good corporate citizens. Forensic Accounting is the specialized field of accounting which ensures that financial statements of the company are prepared according to the applicable accounting standards and principles. Corporate fraud can be curbed with the help of skilled forensic accountants. Corporate frauds and scams have eroded the public image of the companies and it has made them suffer huge losses. Companies have been able to commit fraud because they have the support of top management as it has been seen in many corporate scams such as Satyam Computers fraud.

\section{II.Literature Review}

Rezaee et al. (2004) gathered assessments of the academicians and professionals with respect to the significance, pertinence, and conveyance of measurable bookkeeping training and found that the enthusiasm for scientific bookkeeping was relied upon to proceed to increment and more colleges were wanting to give criminological bookkeeping instruction; the two gatherings of respondents saw legal bookkeeping training as being connected and helpful to bookkeeping understudies, the business network, the bookkeeping calling, and bookkeeping programs; and most of 49 recommended legal bookkeeping points were considered as significant for joining into the bookkeeping educational program by the two gatherings of reviewed academicians and experts. It was discovered that some huge contrasts existed in regard to the topical inclusion of legal bookkeeping among academicians and specialists.

Rathinaraj \& Chendroyaperumal (2010) analyzed some of the issues acknowledged with the operation of the internet for distortion by digital con artists for Financial Fraud and the strategies used. It will similarly give an investigation of the 


\section{Yhternational Research Journal}

p-ISSN 2202-2821 e-ISSN 1839-6518 (Australian ISSN Agency)

current administration and their proficiency in battling this type of cross-outskirt illegal behavior accepting India as a contextual analysis. This paper has introduced the chronicled root of monetary fakes and displays a little study of some famous money related cheats submitted as of late in India.

Bhasin (2013) investigated through an overview study, which was directed in the National Capital Region of India during 2011-12 if there are contrasts in the perspectives on the significant aptitudes of FA among bookkeeping experts, scholastics, and clients of criminological bookkeeping administrations. Altogether, nine inquiries were posed to 40 experts, 80 scholastics and 80 clients of measurable bookkeeping administrations that relate to request their perspectives on what aptitudes are esteemed naturally imperative to FA. At present, a few Universities in India are thinking about adding measurable bookkeeping courses to their educational program. The consequences of the current examination may give some direction to instructors to the advancement of the measurable bookkeeping educational plan by distinguishing the relevant abilities to go with a program of study.

Subash (2015) analyzed the effect of various corporate scams on the financial health of the economy and had also explained the role and importance of forensic accounting in protecting corporate governance. Forensic accounting practices could play a pivotal role in maintaining ethical culture by coordinating companies' efforts to combat fraudulent activities and emerge as good corporate citizens of the country.

Hegazy et al. (2017) explored the nature of forensic accounting in the UK and discovered that criminological bookkeeping in the UK was a multidisciplinary field of action, which was less centered around bookkeeping as there were next to no possibility of turning into a perceived calling within a reasonable time-frame, yet there was a plausibility, in light of groups of individuals with reciprocal aptitudes instead of people with a typical base of authority abilities.

Huber (2017) analyzed the geometry of extortion hypothesis and contended that legal bookkeeping specialists and professionals must perceive that the misrepresentation triangle doesn't have any significant bearing to extortion and must consider that there were n-measurements of budgetary wrongdoing that must be represented in any model that endeavors to clarify, anticipate, forestall, recognize, and arraign money related violations, of which misrepresentation is just a subset.

Kramer et al. (2017) determined views of educators and practitioners regarding forensic accounting education and found that the two gatherings concurred the interest for
Vol. 10 No. 012020

82801001202002

criminological accounting administrations will augment sooner rather than later and that they lean toward a different course or degree be offered at the alumni and undergrad levels, there were a few critical contrasts between the instructors' and experts' conclusions on scientific accounting content and favored enlightening methods.

Eisenberg (2018) dealt with the use of the total assets technique in the monetary wrongdoing contextual analysis of John and Gayle Fawn and indicated that the expansion in total assets and private spending of John and Gayle Fawn could be represented by undisclosed reserve funds from past business salary of John Fawn and by detailed pay for the year 2012/2013. This couldn't have appeared for the years 2013/14 and 2014/15, which comprises a financing hole. It was presumed that the respondents have had the option to represent the total assets increment and private going through with unreported salary in the determined range in 2013/14 and 2014/15.

Nalawade (2019) The increasing number of fakes and the vulnerability of the specialists to battle them have acquired Forensic Accounting in the spotlight. Legal bookkeeping is the claim to fame practice region of accounting that portrays commitment that outcome from the authentic or foreseen case. Criminological bookkeeping is a significant instrument to identify, examine and forestall extortion. To distinguish and forestall monetary fakes and clerical wrongdoings, criminological bookkeeping is utilizing different apparatuses. Right now, the endeavor has been made to examine the different cheats that occurred, and which are constantly hampering the development of the economy and the utilization of Forensic Accounting procedures to battle them. Forensic Accounting analysis helps to assist in legal matters forming the basis for argument, debate and conflict resolution.

Öztürk \& Usul (2020) determined that accounting fraud may occur in enterprises within the framework of forensic accounting through rule-based expert systems. For this purpose, various applications had been implemented in a large-scale production enterprise through the use of rule-based expert systems for the determination of accounting fraud. Benford's Law, risk levels, and various other criteria were used in the creation of expert systems. According to the results obtained from the study, it had been seen that by means of rule-based expert system applications, enterprises can better detect existing frauds and prevent further irregularities in the future. 


\section{Objectives of Study}

The objectives of this study are:

\section{A. Primary objectives}

1. To understand the concept and future scope of forensic accounting

2. To analyze how the frauds can be detected using Information and Communication Technology.

\section{B. Secondary objectives}

1. To understand the techniques for conducting forensic accounting.

2. To analyze major financial scams in India which can be avoided by using forensic accounting.

\section{Methodology}

The information gathered in this study has been taken from secondary sources of data collection including authentic sources as well as past studies. The study is a descriptive analysis of the corporate scams and frauds in India. This study will be helpful for the modern corporate world as they will be able to learn from the past corporate failures and plan for operations strategically.

\section{Observations \& Results}

\section{A. Significance of Forensic Audit}

1. Improve the accuracy of Financial Statements: The forensic accounting helps in identifying any discrepancy in the grounding of financial statements and the report of forensic auditor ensure that the fact and figures are accurate and reliable. It boosts the confidence of the investors in corporate functioning. Forensic Audit makes the financial reports of the companies more reliable.

2. Identification of Asset embezzlement: This is the most common type of fraud been seen. It includes the practice of payments to dummy employees, issuing fake invoices, cash embezzlement, inventory theft, misappropriation of reserves and surplus.

3. Determining the accountability for corruption: When the person committing the fraud uses undue influence to get a personal advantage which is unfavorable to the corporate entity, it leads to the disagreement between the people. Forensic Audit helps in fixing the accountability for the financial crimes, the person having the ultimate authority over the transaction can be held guilty for that particular crime.

4. Early Anticipation of Financial Crimes: Forensic Audit helps in the early detection of frauds as it verifies the transactions frequently, in case of any deviation from the applicable financial reporting standards the matter will be brought to the knowledge of top managerial officials.

\section{B. Areas of Forensic Audit}

1. Fraud Detection: Fraud detection is the process of investigation also, examining money related proof, recognizing budgetary cheats and following the instances of the misappropriated resources.

2. Fraud Prevention: It includes either exploring inside practices to check their skill or giving meeting in the advancement and usage of an interior control system adjusted to an association's hazard profile.

3. Computer Forensic Audit: It includes the practice of creating mechanized applications that help in obtaining authentic and reliable audit evidence via information technology. Computer Forensic audit simply the audit work and it can be performed in a time-bound manner.

4. Providing Expert Testimony: It assists in the legally recognized procedures, including affirmation in the court of law as an expert eyewitness and also helps in getting ready visual guides which act as initial proof.

\section{Techniques for conducting Forensic Accounting}

1. General Audit Techniques

a. Professional Skepticism: This technique requires the auditor to have a questioning mind and empathize with their suspect. These skills of the auditor will help them to find the culprit behind the fraud. As per SA-200 "Overall objectives of the independent auditor", the auditor should possess professional skepticism to find the facts which have been hidden so far to commit the financial frauds.

2. Statistical and Mathematical Techniques:

a. Trend Analysis: It includes the review of past transactions to analyze the trend and it helps the auditor to decide the future course of action.

b. Ratio Analysis: Data analysis ratios and financial ratios can be of utmost importance to find instances of fraud. These ratios will help the auditor in deciding the substantive audit procedures to carry out the audit proceedings. The ratio analysis will help the auditor in comparing the data of two years and he will be able to find out the reasons for variation in the financial data. 
3. Digital Forensic Techniques: Cyber forensics is the process of identifying, analyzing, preserving and presenting electronic evidence in an approach that has legal acceptability in the judiciary. In the technologydriven era, forensic accounting also involves scrutiny of the accounting files and documents, relevant emails, phone logs and hard drives which is the requirement of the modern forensic audit. Nowadays advanced excel is also used to find out the possibility of fraudulent transactions with the help of Excel Formulae.

4. Data Mining Techniques: For data mining, there is specific audit software that helps in extraction, classification, clustering of data, regression analysis and retrieval of data. Data Mining helps in the identification of patterns so that new knowledge can be extracted from the information provided to forensic auditors. The historical data available will provide the groundwork for future predictions using data mining techniques.

5. Interviewing the Suspects: The forensic auditor should possess the interrogating and interviewing skills which will help to find the culprit and put them behind the bars.

\section{Major Scams in India}

In India being ranked as the 88th most corrupt nation, due to the white-collar crimes and financial scams, the interest of public incorporate and Indian judicial system is deteriorated and the ongoing cases of corporate frauds have raised the need for proper system for monitoring the financial frauds, Forensic Accounting has come into the limelight to prevent the menace of corporate frauds. Some of the biggest scams and malpractices are as follows:

1. Ketan Parekh Scam: Ketan Parekh was associated with stock control and roundabout exchanging all the way from 1999-2001 of a large group of organizations. He acquired from banks like Global Trust Bank and Madhavpura Mercantile Co-employable bank and controlled a large group of shares prevalently identified as K-10 stocks. IT system found out the discrepancies in the sources of funds of KP. Major flaws that were found were trading system, credit check, High exposure allowed, lack of records and margins at Calcutta stock exchange and lending without proper approval.

2. Sahara Group Scam: Sahara Group executive Subrata Roy and Vijay Mallya had energy for sports and both of them also had their own IPL groups, to be specific Sahara Pune Warriors and Royal Challengers
Bangalore. The case caught the attention when a Chartered Accountant located in Indore send a message to the National Housing Bank, requesting the bank to gaze into the housing bonds issued by two Sahara Group Companies i.e Sahara India Real Estate Corp (SIREC) and Sahara Housing Investment Corp (SHIC). It has been pragmatic that bonds have been issued without complying with the SEBI guidelines. In the Draft Red Herring Prospectus, the company was shown as a private limited company but it has operated as a public limited company to defraud the general public. Sahara Scam has been accused of the cases of money laundering, fictitious investors and dummy shares against it.

3. Forensic Audit on PNB Scam: It is one of the biggest scams in the banking industry. Punjab National Bank delegated a BDO to direct a criminological review of diamond setter Nirav Modi's organizations. The bank gave a conventional arrangement letter to the Belgium-headquartered review firm on February 27, 2018 , to lead a scientific review in the trick wherein Modi, his uncle Mehul Choksi and their organizations have been blamed for duping the bank of as much as Rs 12,700 crore. The Central Bureau of Investigation (CBI) got two protests from PNB against very rich person diamantaire Nirav Modi and Jewelry Company claiming fake exchanges worth about Rs. 11, 400 crores. The auditors of the PNB were held guilty of gross negligence. Overseas banks such as Allahabad Bank, Axis Bank and Union Bank of India for overlooking the NOSTRO accounts. The case falls under Section 420 of the Indian Penal Code and Section 120 B Criminal Conspiracy.

4. Forensic Audit on Dena Bank: The Finance Ministry has ordered a forensic audit on Dena Bank and OBC following the scams to the tune of Rs. 437 crore. It has been found that some of their branches located at Mumbai were purportedly misappropriating funds worth Rs. 437 crores gathered through fixed deposits. In the case of Dena Bank, the embezzlement was of Rs. 257 crore and associated with funds mobilized from seven companies. In Oriental Bank's case, it related to the misappropriation of funds amounting to Rs. 180 crores, allegedly belonging to the Jawaharlal Nehru Port Trust. The incidents have brought to the forefront the weak risk management systems in public sector banks. These occasions of misappropriation have occurred at the branch level due to an absence of due determination and non-adherence to standards. The episode in Oriental Bank of Commerce dated 
February 2014 and the bank had gotten the ball rolling from the get-go in March itself to halt the fixed store trick from the beginning, said Shri Bansal. Of the underlying measure of Rs. 180 crores, as much as Rs. 110 crores were promptly recouped and given over to the first remitter.

5. Satyam Computers Fraud: B Ramalinga Raju, the inventor of Satyam Computers, fell into difficulty after he confessed to expanding the organization's income, benefit and overall revenues for each and every quarter over a time of 5 years, from 2003-2008. The sum misused right now assessed to associate with Rs. 7,200 crores. He had issued bogus invoices to raise the revenue of the company. In April 2015, the suspects of the case were sentenced to 7 years of imprisonment and also charged a penalty of Rs 5.5crore. There were apparent facts that showed lack of good corporate governance such as non-payment of government dues, the composition of directors was not as per the SEBI (LODR), 2015, the audit committee was not constituted as per section 177 of the Companies Act 2013, the credit rating agencies such as CARE, ICRA, etc., misguided the investors by issuing phony ratings to the corporate entities, bank issued short term loans to companies without proper verification, mortgage security and fake audit was conducted by Pricewaterhouse Coopers (PwC).

6. PwC to do Forensic Audit of Cox \& Kings: Suspecting fraud, lenders to Cox \& Kings, the tour and travel company that have defaulted on loan payments, have initiated a forensic investigation into the matter and the role if any of senior executive and the Indian promoters. After taking over the Cox \& Kings following the series of defaults, the lenders discovered that the company had only 8 crores in an FD. The bankers also found that all computers, laptops and IT systems in the company were copied clean and locked. The Forensic investigator had managed to unlock the computers and laptops, but all the crucial data have been wiped out. Also, some of the facts and figures are shown in the published results of the company do not tally with the ground reality. All buildings and offices of the company were also on the lease as well. In October 2019 Rattan Tata Finance, one of the creditors to Cox \& Kings dragged the company to NCLT in Mumbai. As per the NCLT plea the Co. had defaulted on a Rs 30 crore loan. An email sent to Insolvency Professional did not elicit any response.

\section{E. The emerging role of Cyber Forensics in India:}

When a forensic audit is conducted with the help of information technology it is known as cyber forensics. It comprises of Digital Forensics, Cyber Laws, Cyber Laws, Ethical hacking, Data Extraction, and Digital Incident Response. In cyber crimes, computer system or the internet is used as an instrument to commit financial crimes. Cybercriminals are the people who have expertise in the fields of information technology and communication networks, and they make use of their excellence in committing cyber frauds. Cybercrimes do not have any physical constraint and they do not feel any territorial boundary. The online data needs to be protected from malicious intruders and cybercriminals. Cyber Forensic Accountants carry out the investigation with the help of valuable Information Technology professionals. Crime has been classified as the Target Cyber Crime, in this crime computer is the subject matter of crime, Tool Cyber Crime, in this crime the server is used as a tool for committing offense and lastly, we have Computer Incidental, in this servers have very little rule to play, servers have limited role in commission of offense.

\section{F. Future Scope of Forensic Accounting in India:}

Forensic accounting is the prerequisite for the corporate and government department due to the rising scams in the country. There is a huge necessity for honesty, fairness, and transparency in Indian Corporate reporting.

- Lack of Skilled Forensic Auditors: In India, accounting bodies have been in process of introducing Forensic Accounting in the curriculum of universities, that's why forensic accountants are not easily available who possess requisite technical knowledge and expertise.

- Cyber Crimes: Due to the rise in the financial crimes conducted via information technology cyber forensics have emerged to be a new domain for forensic accountants to work on.

- Political Involvement: In India, most of the scams arise due to the involvement of politicians, and it becomes crucial to find pieces of evidence against them.

- Mergers and Acquisitions: In the case of mergers Forensic Investigation are conducted as a part of due diligence.

- $\quad$ Red Flagged Accounts: RBI Red Flagged Accounts needs forensic, incoming period RBI may make it compulsory for advances above a certain threshold.

- Serious Fraud Investigations Office: Corporate and economic laws mandate the appointment of Serious Fraud Officer under the Ministry of Corporate Affairs 
who have the ability to handle corporate frauds and carry out the investigation against the white-collar fraudsters.

- Economic Offences Wings: It also requires the help of experienced Accountants in Forensics.

- Instances of Internal Frauds: Many National Companies have internal irregularities that can be taken care of by the appointment of internal auditors who can check the adequacy of internal controls by applying standards on auditing.

- Economic Laws: The Insolvency and Bankruptcy Code, 2016 have encountered various cases where forensic accountants are required to figure out the suspect behind the financial crime.

- Enhancing Career Avenues: As a profession, forensic auditing is exceptionally worthwhile, as the reports generated by forensic accountants are more trustworthy, accurate and reliable. Skilled forensic auditors are in great stipulate and can simply earn a prominent better salary across the world.

- Helps in Investment Decision Making: Forensic accounting helps in analyzing the financial position which provides a lane for investors to make improved and better financial decisions. Forensic accounting helps in the preparation of due diligence report which helps the company in taking corporate restructuring decisions.

- Help the Government in the formulation of Economic Policies: It helps the government to devise better economic policies that would be able to control fraudulent actions in the upcoming arena. With the help of improved economic policies, the government can build up the economy and put a stop to such illegal activities in the country.

\section{Conclusion}

The explicit objective of this study is to create an understanding of forensic accounting in India. Cyber Forensics has revolutionized the scope of forensic accounting. There are various techniques such as benchmarking, ratios analysis, specialist software, system analysis, etc, which can be employed beforehand to curb the malpractices of companies. Due to the increasing number of scams in India, it is the need of the hour to have forensic professionals to handle the cases of financial frauds and scams. In India, frauds have been rising at a fast pace due to a lack of proper monitoring and control mechanisms. Companies have to comply with the laws and regulations so that they are less prone to penalties and legal actions and it will help them to emerge as good corporate citizens. Forensic Accounting is the focused field of accounting which ensures that financial statements of the company are prepared according to the applicable accounting standards and principles. On the basis of the scams in the past, we have seen in this paper that India has already encountered heavy losses due to major corporate frauds. Due to various corporate failures, the government has set up various investigating offices such as Serious Fraud Office that has been set up for recognition and anticipation of economic irregularities and scams and the Central Vigilance Commission deals with cases of fraud and bribery. The companies should comply with the SEBI guidelines and provisions of Listing obligations and Disclosure Requirements (LODR),2015 Due to the rise in frauds, the government has made amendments in corporate and economic laws such as the Prevention of Money Laundering Act and Insolvency Act, etc. As a Forensic professional, Forensic Accounting has a promising future in India due to the increase in corporate frauds and white-collar crimes. In a nutshell, it can be concluded that Forensic Accounting ensures the inclusive growth of the economy and helps in unveiling the unethical practices followed by big corporate giants.

\section{References}

[1]. Atağan, G., \& Kavak, A. (2017). Relationship between fraud auditing and forensic accounting. International Journal of Contemporary Economics \& Administrative Sciences, 7.

[2]. Bhasin, M. L. (2013). Corporate governance and forensic accountant: An exploratory study. Journal of Accounting, Business and Management (JABM), 20(2).

[3]. Bhasin, M. L. (2016). Creative accounting scam at Satyam computer limited: how the fraud story unfolded?. Open Journal of Accounting, 5(04), 57.

[4]. Bologna, J., \& Lindquist, R. J. (1995). Fraud auditing and forensic accounting: new tools and techniques. John Wiley \& Sons Inc.

[5]. Collin Greenland (2001), Demystifying Forensic Accounting, The Weekend Observer, Pg.5, December 7, 2001.

[6]. Crain, M. A., Hopwood, W. S., Gendler, R. S., Young, G. R., \& Pacini, C. (2019). Essentials of forensic accounting. John Wiley \& Sons.

[7]. Davis, C., Farrell, R., \& Ogilby, S. (2010). Characteristics and skills of the Forensic Accountant. American Institute of Certified Public Accountants.

[8]. Eisenberg, P. (2018). Application of the net worth method in forensic accounting investigations. International Research Journal of Multidisciplinary Studies, 4(10), 1-23. 
[9]. Gligorić, M. (2017). The purpose of forensic accounting in detecting occupational fraud in contemporary corporate governance. Challenges in Modern Corporate Governance.

[10]. Hegazy, S., Sangster, A., \& Kotb, A. (2017). Mapping forensic accounting in the UK. Journal of International Accounting, Auditing and Taxation, 28, 43-56.

[11]. Huber, W. (2017). Forensic accounting, fraud theory, and the end of the fraud triangle. Journal of Theoretical Accounting Research, 12(2).

[12]. Kramer, B., Seda, M., \& Bobashev, G. (2017). Current opinions on forensic accounting education. Accounting Research Journal, 30(3), 249-264. Retrieved from: https://scholarworks.montana.edu/xmlui/bitstream/ha ndle/1/14943/Kramer_ARJ_2018_A1b.pdf?sequence =1\&isAllowed=y, accessed on 1 February 2020.

[13]. Kranacher, M. J., \& Riley, R. (2019). Forensic accounting and fraud examination. John Wiley \& Sons.

[14]. Kranacher, M. J., Morris, B. W., Pearson, T. A., \& Riley Jr, R. A. (2008). A model curriculum for education in fraud and forensic accounting. Issues in Accounting Education, 23(4), 505-519.

[15]. Kumar, D. R., \& Vijayalaksmi, D. (2018). A study on role and responsibility of forensic accounting in fraud detecetion and legal disputes. International Journal of Management and Social Sciences (IJMSS), 8(1.4), 147-148.

[16]. Kurnaz, N., Köksal, I., \& Ulusoy, T. (2019). Forensic accounting in financial fraud control in digital environment: A research on independent auditors. Electronic Turkish Studies, 14(3).

[17]. Lakshmi, P., \& Menon, G. (2016). Forensic accounting: A checkmate for corporate fraud. Journal of Modern Accounting and Auditing, 12(9), 453-460.

[18]. Moid, S. (2016). Application of forensic accounting to investigate scams in India. MIJBRMITS International Journal of Business Research, 3(1), 2431.

[19]. Nalawade, s. r. m. (2019). role of forensic accounting in combating the scams of banking sector in india. bims international research journal of management and commerce, 4(1).

[20]. Nigrini, M. J. (2011). Forensic analytics: methods and techniques for forensic accounting investigations (Vol. 558). John Wiley \& Sons.

[21]. Öztürk, M. S., \& Usul, H. (2020). Detection of Accounting Frauds Using the Rule-Based Expert
Systems within the Scope of Forensic Accounting (Vol. 102, pp. 155-171). Emerald Publishing Ltd.

[22]. Peshori, K. S. (2015). Forensic Accounting a Multidimensional Approach to Investigating Frauds and Scams. International Journal of Multidisciplinary Approach \& Studies, 2(3).

[23]. Prakash, N. (2013). Forensic Accounting: A Budding Field in India. Indian Journal of Accounting, 45(1), 102-111.

[24]. Rezaee, Z., Crumbley, D. L., \& Elmore, R. C. (2004). Forensic accounting education: A survey of academicians and practitioners. Advances in Accounting Education, Forthcoming. Retrieved from: http://mohammedshanikat.synthasite.com/resources/F orensic\%20Accounting\%20\%20eduaction.pdf, accessed on 1 February 2020.

[25]. Smith, G. S., \& Crumbley, D. L. (2009). Defining a forensic audit. Journal of Digital Forensics, Security and Law, 4(1), 3.

[26]. Sofianti, S. P. D., Ludigdo, U., \& Irianto, G. (2014). The perception of the practitioners and students towards the subject of forensic accounting and fraud examination. Journal of Economics, Business, \& Accountancy Ventura, 17(2), 281-292.

[27]. Stone, D. N., \& Miller, T. C. (2012). The state of, and prospects for, forensic and fraud research that matters. Journal of Forensic \& Investigative Accounting, 4(2), 35-76.

[28]. Subash, T. (2015). Forensic accounting and Corporate Governance. EXCEL International Journal of Multidisciplinary Management Studies, 5(11), 4954. 